\title{
Evaluasi Pelaksanaan Standar Proses di Satuan Pendidikan Anak Usia Dini
}

\author{
Nurdin' ${ }^{1}$, La Ode Anhusadar ${ }^{2}$ \\ Pendidikan Islam Anak Usia Dini, Institut Agama Islam Negeri Kendari \\ DOI: $\underline{10.31004 / \text { obsesi.v4i2.485 }}$
}

\begin{abstract}
Abstrak
Penelitian ini dilakukan dengan tujuan untuk mengetahui proses perancanaan pembelajaran, pelaksanaan pembelajaran dan penilaian pembelajaran. Metode penelitian ini adalah metode evaluasi model CIPP. Lokasi penelitian ini adalah KB Nur'ain di Mola Selatan Kecamatan Wangi-wangi Selatan Kabupaten Wakatobi. Teknik Pengumpulan data adalah teknik observasi, wawancara dan dokumentasi. Hasil penelitian ini adalah perencanaan dan penyusunan program semester dan kegiatan harian masih dilakukan oleh para guru dengan menyontek buku yang dibeli. Kelompok Bermain Nur'ain baru sebatas membuat rencana kegiatan harian sesuai dengan buku tanpa melakukan modifikasi. Kegiatan pelaksanaan pembelajaran meliputi pembukaan, inti dan penutup sebagaimana tertuang dalam standar PAUD. Kegiatan masih dominan terjadi di dalam kelas dengan suasana teacher center yang menekankan pembelajaran pada kognisi anak. Dari sisi metode pembelajaran, maka belum sesuai dengan standar PAUD. Penilaian pada Kelompok Bermain Nur'ain ini melakukan penilaian melalui pengamatan dan unjuk kerja, penilaian tersebut tidak dicatat secara individu melalui narasi melainkan berkelompok dengan memakai simbol angka.
\end{abstract}

Kata kunci: evaluasi; proses; standar paud.

\begin{abstract}
This reasearch aims at knowing the process of learning plan, implementation of learning and learning evaluation. The reasearch method used in this research is CIIP model evaluation method by qualitative approach. It is conducted in Playgorp Nur'ain West Mola, WangiWangi distcrict, Wakatobi island. The subject of the research are it's headmaster and teacher. In data collection, the reserach uses observation, interview and documentation. The result finds that planning and preparation of semester program and daily activities are still carried out by teachers in terms of copying books puchased. Nur'ain Play Group is only limited to making daily activity plans accordinig to the book course without modification. This course raises question of why this habis continues to be maintained even though the schools should be able to make their own learning plans. Thus, this process is not accordance with PAUD standards. Learning implemetation includes of opening, core and closing step as set out in PAUD standards. Nevertheless, the activity is still dominanti teacher-center atmosphere that emphasizes learning of children's cognition. Assesements are still conducted through observation and performances. However, these assesments are not recorded individually through narration rather in groups using numerical symbols.

Keywords: evaluation, process, early childhood education's standard.
\end{abstract}

Copyright (c) 2020 Nurdin, La Ode Anhusadar

$\triangle$ Corresponding author:

Email Address sadar.wanchines@gmail.com (Kendari, Indonesia)

Received 2 March 2020, Accepted 12 March 2020, Published 14 March 2020

982 | Jurnal Obsesi : Jurnal Pendidikan Anak Usia Dini, 4(2), 2020 


\section{PENDAHULUAN}

Anak usia dini yaitu anak yang sedang berada dalam pertumbuhan dan perkembangan yang pesat baik itu fisik atau psikis serta anak-anak yang berusia dibawah 6 tahun. Jadi mulai dari anak lahir hingga ia mencapai umur 6 tahun ia akan dikategorikan sebagai anak usia dini. Menurut Piaget dalam Sumantri anak usia dini berada pada masa lima tahun pertama yang disebut The Golden Age. Masa ini merupakan masa emas perkembangan anak (Sumantri, 2005). Menurut Agus Surono bahwa perkembangan otak anak yang sedang tumbuh melalui tiga tahapan, mulai dari otak primitif (action brain), otak limbik (feeling brain), dan akhirnya ke neocortex (atau disebut juga thought brain, otak pikir) (Anhusadar, 2018). Pada periode ini hampir seluruh potensi anak mengalami masa peka untuk tumbuh dan berkembang secara cepat. Apabila anak mendapatkan stimulus yang baik, maka seluruh aspek perkembangan anak akan berkembang secara optimal. Salah satu aspek yang penting untuk dikembangkan adalah aspek perkembangan motorik terutama motorik halus.

Manusia membutuhkan pendidikan dalam kehidupanya pendidikan merupakan usaha agar dapat mengembangkan potensi melalui proses pembelajaran. Taman kanakkanak merupakan salah satu bentuk pendidikan anak usia dini yang ada di jalur pendidikan sekolah. Anak usia dini menurut Sistem Pendidikan Nasional No. 20 Tahun 2003 pasal 1 ayat 14 adalah anak yang berada pada usia lahir sehingga usia 6 tahun. Pada anak usia dini mengalami pertumbuhan dan perkembangan yang sangat pesat sehingga membutuhkan stimulasi yang sesuai dengan kebutuhan anak-anak. Stimulasi tersebut salah satunya dapat diperoleh dari pendidikan anak usia dini. Pendidikan anak usia dini merupakan upaya pembinaan dan melalui pemberian rangsanagan pendidikan untuk meembantu pertumbuhan dan perkembangan jasmani dan rohani agar anak dapat memiliki kesiapan dalam memasuki pendidikan lebih lanjut (Suyadi, 2010).

Anak usia dini merupakan dasar awal yang menentukan kehidupan suatu bangsa dimasa yang akan datang, sehingga diperlukan persiapan generasi penerus bangsa dengan mempersiapkan anak untuk tumbuh dan berkembang secara optimal baik dalam perkembangan moral, fisik/motorik, kognitif, bahasa, maupun sosial emosional. Setiap anak berhak untuk mendapatkan penghidupan dan perlindungan yang layak, serta dapat tumbuh dan berkembang secara optimal (Anhusadar \& Islamiyah, 2019). Pendidikan Anak Usia Dini merupakan pendidikan yang diselenggarakan untuk mengembangkan keterampilan yang merupakan pendidikan dasar serta mengembangkan diri secara utuh sesuai dengan asas pendidikan sedini mungkin dan sepanjang hayat. Aspek yang dikembangkan dalam pendidikan anak usia dini adalah aspek pengembangan pembiasaan meliputi sosial, emosi, kemandirian, moral, dan nilai-nilai agama, serta pengembangan kemampuan dasar yang meliputi pengembangan bahasa, kognitif, dan fisik motorik (Musfiroh, 2008).

Salah satu bentuk lembaga pendidikan anak usia dini yang berada pada jalur formal adalah taman kanak-kanak (TK) yang berusia 5-6 tahun. Tujuan pendidikan di TK untuk pencapaian perkembangan yaitu : Nilai agama dan moral, fisik motorik kasar, motorik halus, kesehatan fisik, kognitif yaitu pengetahuan umum dan sains, konsep bentuk warna ukuran dan pola, konsep bilangan lambang bilangan dan huruf, bahasa yaitu menerima bahasa, mengungkapkan bahasa, keaksaraan, sosioal emosional. Kreativitas anak usia dini dapat diupayakan melalui permainan yang dirancang oleh Pendidik di Lembaga PAUD, karena dengan permainan anak dapat mengembangkan serta mengintergrasikan semua potensinya, sehinga mereka lebih kreatif. Peran Pendidik dalam kegiatan permainan anak adalah memberikan dorongan, membimbing bermain bagi anak dan membantu anak mengembangkan potensinya, sehingga mereka menjadi anak yang kreatif (Anhusadar, 2016). Kompetensi tutor/pendidik paud dalam merancang model pembelajaran yang inovatif berbasis kearifan budaya local dapat dideskripsikan sebagai berikut: a). Pendidik sudah menentukan tema pembelajaran yang sesuai potensi lokal; b). Tema-tema yang dipilih sudah berbasis kearifan budaya lokal; c) Adanya kesesuaian antara indikator dengan materi 
pembelajaran; d) Adanya kesesuaian antara tema dengan kegiatan pembelajaran; e) Adanya keterpaduan antara materi pembelajaran dengan kegiatan pembelajaran yang dilakukan anak; f) Media pembelajaran (APE) sudah memanfaatkan potensi budaya local (Munawar, Prasetyo, \& Pusari, 2013).

Pelaksanaan proses belajar pada PAUD perlu dilakukan pengembangan mengingat pentingnya masa golden age. Evaluasi pada bagian pelaksanaan pembelajaran umumnya menunjukkan hasil yang kurang maksimal jika dibandingkan dengan aturan dalam standar PAUD. Terlihat di setiap lembaga PAUD sudah ada penataan lingkungan ruang kelas dan pengorganisasian kegiatan, namun masih terkesan kaku. Rata- rata lembaga PAUD mempunyai ruang kelas yang sudah dirancang secara permanen, yaitu area dan peralatan telah ditetapkan pada lokasi masing-masing dengan maksud tidak akan berubah lagi pada kegiatan belajar, sampai anak didik menyelesaikan program belajarnya di PAUD (Kasrani, 2016). Evaluasi juga telah dilakukan oleh semua lembaga PAUD, walaupun masih ada instrumen evaluasi pembelajaran yang bervariasi, ada beberapa lembaga yang memiliki intrumen evaluasi lengkap dan ada yang masih kurang lengkap. Kemudian pengawasan pembelajaran PAUD oleh kepala satuan PAUD atau yang sering disebut sebagai penilik dari dinas pendidikan telah dilaksanakan secara berkala di Keluarahan keluarahan Air Tawar Barat Kota Padang. Sehingga proses pelaksanaan belajar dan mengajar di PAUD dapat terlaksana dengan efektif. Hanya saja masih diperlukan penyetaraan intrumen evaluasi pembelajaran PAUD di Keluarahan keluarahan Air Tawar Barat Kota Padang (Yati \& Yaswinda, 2019).

Perencanaan pembelajaran belum menjamin kesuksesan proses pembelajaran, karena proses penyampaian atau pengimplementasian dari rencana itulah yang justru menentukan efektivitas dari suatu proses pembelajaran. Maka, dalam kaitan dengan evaluasi proses, kedua lembaga belum memenuhi standar PAUD sepenuhnya. Di lapangan, penyusunan RPPM dan RPPH belum dilakukan secara maksimal dan tertib, dikarenakan pendidik merasa sudah memiliki RPPM dan RPPH yang sudah jadi dan terkadang kurang dimodifikasi. Selain itu, jika peserta didik terlalu lama mengerjakan atau bahan pembelajaran tidak tersedia, maka jarang RPPH yang telah dibuat jadi bergeser (Utami, Jamaris, \& Meilanie, 2019). Penelitian yang dilakukan oleh Hermawati di TPA Beringharjo Yogyakarta menemukan dua kelemahan dari varia- bel input, yaitu kualifikasi pendidikan peng- ajar dan pengasuh yang tidak relevan dengan bidang tugas. Pada variabel proses, permasalahannya adalah belum terukurnya kegiatan pendampingan oleh pengasuh. Hal ini terkait dengan pendidikan pengasuh yang mayoritas rendah. Selain itu, belum dilakukannya pendampingan secara teratur oleh penyelenggara serta akses masyarakat terhadap TPA Beringharjo terbatas karena terbatasnya daya tamping (Gunartha, Kartowagiran, \& Suardiman, 2014).

Kegiatan-kegiatan yang direncanakan sebagian besar telah terlaksana dengan baik dengan penyesuaian kegiatan sesuai kondisi dan kebutuhan. Kendala yang ada, baik dari atau berhubungan dengan pribadi guru, kepala sekolah, manajemen sekolah, maupun sarana-prasarana, dapat ditangani dengan baik. Kesiapan dan partisipasi kepala sekolah maupun para guru mendukung pelaksanaan program supervisi akademik. Dokumentasi yang lengkap dan lebih terstruktur terhadap kegiatan yang telah diadakan perlu lebih ditingkatkan (Kurniawan, Dwikurnaningsih, \& Sulasmono, 2018). Bermain adalah bentuk pembelajaran yang khas di PAUD, termasuk di dalamnya TPA juga. Guna mengakomodasi kegiatan bermain yang sesuai dengan anak maka dibutuhkan sebuah lingkungan yang kondusif dan responsif karena lingkungan juga berperan dalam mengembangkan potensi dan keterampilan anak. Dimensi lingkungan TPA tidak terlepas dari keberadaan sarana dan prasarana (Widiastuti, 2018).

Guru perlu meningkatkan ketersediaan sarana mengajar dan belajar anak yang bervariasi dengan cara menyiapkan materi belajar yang terus berganti sesuai dengan tema belajar agar anak tidak bosan dan dapat belajar banyak hal (V \& Anamara, 2014). Prosedur 
penataan lingkungan bermain sudah tercantum dalam buku panduan di RA Istiqlal Jakarta sesuai dengan kriteria keberhasilan. Akan tetapi, belum adanya penjadwalan khusus (alokasi waktu) dalam program penataan lingkungan bermain, semua berjalan sesuai kebutuhan para guru dan hanya secara lisan dapat dilakukan di pagi hari atau sore hari sebelumnya (Renti Oktaria, 2019). Guru pendamping sentra perlu meningkatkan keterampilannya dalam menerapkan lima continum, meliputi: pengamatan, pernyataan tidak langsung, pernyataan lang- sung, pertanyaan, dan intervensi fisik yang harus sesuai dengan prinsip dalam pendekatan BCCT saat mendampingi anak bermain (Oktaria, 2014). Proses pembelajaran yang tidak terrencana dengan baik, jelas dan sesuai mulai dari program semester RPPM dan RPPH, tidak sesuai mekanisme kerjanya yang sistematis dan terorganisir, memberikan dampak pada menurunnya kinerja guru dalam perencanaan, pelaksanaan, penilaian pembelajaran dalam melahirkan dokumen pencapaian perkembangan yang tepat waktu dan tepat kegunaan (Marwah, 2017).

Kriteria tentang pelaksanaan pembelajaran pada satuan atau program PAUD dalam rangka membantu pemenuhan tingkat pencapaian perkembangan yang sesuai dengan tingkat usia anak. Standar Proses mencakup perencanaan pembelajaran, pelaksanaan pembelajaran, evaluasi pembelajaran, dan pengawasan pembelajaran. Proses pelaksanaan pembelajaran dilakukan melalui bermain secara interaktif, inspiratif, menyenangkan, kontekstual, dan berpusat pada anak untuk berpartisipasi aktif serta memberikan keleluasaan bagi prakarsa, kreativitas, dan kemandirian sesuai dengan bakat, minat, dan perkembangan fisik serta psikologis anak (Hartati, 2017).

\section{METODOLOGI}

Metode penelitian yang digunakan dalam penelitian ini adalah metode evaluasi model CIPP dengan pendekatan kualitatif. Lokasi penelitian ini adalah Kelompok Bermain Nur'ain di Mola Selatan Kecamatan Wangi-wangi Selatan Kabupaten Wakatobi. Teknik yang dapat digunakan untuk pengumpulan data dapat berupa: observasi dilakukan untuk mengamati fasilitas sarana dan prasarana dari lembaga PAUD yang bisa menunjang kegiatan anak serta mengamati proses pembelajaran yang berlangsung sesuai dengan rencana kegiatan harian atau tidak. Wawancara untuk memperoleh data dari informan mengenai pelaksanaan Permendikbud No. 137 tahun 2014 pada PAUD di kabupaten Wakatobi. Informan terdiri dari pemerintah daerah, pendidik, kepala sekolah dan orang tua siswa. Dokumentasi kegiatan-kegiatan apa saja yang dilakukan anak di lembaga PAUD, buku pedoman tumbuh kembang anak dan buku perkembangan anak serta bahan ajar.

Tabel Penelitian CIPP.

\begin{tabular}{lll}
\hline NO & \multicolumn{1}{c}{ CIPP } \\
& (PROCESS) & \multicolumn{1}{c}{ PERMENDIKBUD NO. 137 Tahun 2014 } \\
\hline 1 & Perencanaan Pembelajaran & Standar Tingkat Pencapaian Perkembangan \\
2 & Pelaksanaan Pembelajaran & Anak Usia Dini, Standar Proses dan \\
3 & Penilaian Pembelajaran & Standar Penilaian \\
\hline
\end{tabular}

\section{HASIL DAN PEMBAHASAN}

\section{Perencanaan Pembelajaran.}

Perencanaan pembelajaran yang dimiliki Kelompok Bermain Nur'ain, nampak bahwa perencanaan aspek pengembangan pembelajaran di lembaga ini sudah meliputi nilai agama dan moral, fisik, kognitif, bahasa, sosial emosional dan seni sebagaimana terlihat dalam program harian yang disusun. Hasil wawancara dengan kepala sekolah diperoleh lnformasi bahwa program harian tersusun bersama guru-guru dan kepala sekolah, sebagaimana dituturkannya dalam wawancara, "Susunan Rencana Pelaksanaan Pembelajaran Harian (RPPH), kami lihat tema ini berapa minggu diajarkan, temanya apa, 
nomor indikatornya berapa, semester ke mingguan serta harian (Wawancara Kepala Sekolah, 28 Agustus 2019).

Kepala sekolah juga menambahkan informasi bahwa tidak ada kendala yang mereka hadapi saat menyusun kegiatan semester, seperti yang diungkapkannya "Saya rasa tidak ada kendala karena kami sudah bagi per tema per kelompok" (Wawancara Kepala Sekolah, 28 Agustus 2019). Namun jika diamati dengan baik dokumen kegiatan harian, rnaka akan ditemukan bahwa banyak terjadi pengulangan atau copy paste indikator pada tiap tema yang diusulkan, yang berubah hanyalah tema dan sub tema sedangkan kegiatannya indikator tidak berubah.

Informasi tersebut sejalan dengan informasi yang diperoleh dari kepala sekolah. Berdasarkan hasil, berdasarkan wawancara terhadap beberapa guru-guru, diperoleh informasi bahwa penyusunan program harian dan rencana kegiatan harian tidak disusun oleh pihak sekolah melainkan disusun bersama para guru yang yang bersumber dari buku yang kami pesan dari luar daerah yang sudah lengkap kegiatan hariannya, sebagaimana dituturkan bu Rusnia bahwa: "Penyusunan kegiatan harian dan semester di sekolah biasanya kami susun secara bersama yang bersumber dar buku yang kami pesan dari luar daerah" (Wawancara Guru R, 28 Agustus 2019).

Meski demikian, ada juga guru yang mengatakan bahwa sekolah memiliki guru yang bertugas untuk menyusun program harian dan rencana kegiatan semesteran. Program semester dan rencana kegiatan harian ini kemudian menjadi bahan diskusi dalam forum diskusi guru-guru Kelompok Bermain, seperti yang diungkapkan Windasari bahwa seksi kurikulum sekolah juga ada, kami akan buat kurikulum yang kami gunakan dalam proses pembelajaran. Ada dua orang guru yang bantu buat kurikulum. Mereka buat kegiatan semester, kegiatan harian kami bikin sendiri. Waktu uji coba RPPH kami buat bagi sesuai dengan jadwal dari kepala sekolah, sesuai dengan jadwal yang kami telah buat (Wawancara Guru W, 28 Agustus 2019).

Untuk mendapatkan informasi yang transparan berkenaan dengan alasan penyusunan program kegiatan tahunan dan harian yang harus disusun bersama guruguru. Kelihatan bahwa peran buku panduan yang dipesan dari luar daerah begitu kuat di kalangan kepala sekolah, guru dan sekolah, sehingga kegiatan pembelajaran di sekolah pun harus bersumber dari buku panduan. Jika program semester disusun bersama oleh para guru dan kepala sekolah. maka kegiatan hariah disusun oleh masing-masing guru dengan batas waktu yang ditentukan sendiri, maksudnya guru-guru dapat menyusunnya untuk kegiatan seminggu atau dapat juga disusun sehari sebelum kegiatan belajar mengajar terjadi. Hal ini sebagaimana dikatakan oleh Windasari bahwa: "Tergantung dari guru, kalau mau mengajar untuk besok kalau kita susun hari ini kita susun pokoknya tergantung dari gurulah kalau guru rajin susun seminggu sebelumnya (Wawancara Guru W, 28 Agustus 2019).

Guru W juga menyatakan bahwa ada dua kebiasaan guru di sekolah dalam menyusun rencana kegiatan harian yakni disusun untuk janqka waktu satu minggu, atau disusun sehari sebelum kegiatan belajar diadakan, seperti diungkapkannya: "Susun di sekolah kalau ada waktu bisa di rumah atau di sekolah, Kalau guru ada waktu bisa susun untuk seminggu, kalau tidak ada waktu bisa susun hari ini untuk besok, yang penting harus ada" (Wawancara Guru W, 28 Agustus 2019).

Ada dua hal menarik berkaitan dengan pernyataan para guru terhadap penyusunan rencana harian, pertama rencana harian bisa disusun untuk seminggu, dan ini berlaku bagi guru yang rajin dan sebaliknya bisa disusun sehari sebelum kegiatan belajar. Kedua, empat guru sepakat menyatakan bahwa RPPH penting. Lantas apakah ada kendala yang ditemukan selama penyusunan RPPH? Dengan spontan, keempat guru dalam wawancara menyatakan tidak ada kendala dalam menyusun RPPH. Menurut mereka menyusun RPPH adalah pekerjaan yang mudah karena pengalaman mengajar mereka yang rata-rata sudah lebih dari 8 tahun. seperti yang diungkapkan Windasari bahwa "tidak masalah karena sudah 
8 tahun jadi harus jadi panutan. Tapi kalau yang baru sistem sentra masih uji coba dengan sekolah-sekolah yang lain, sekolah kami masih belajar untuk menyempurnakan RPPH" (Wawancara Guru W, 28 Agustus 2019). Pendapat Guru W, diperkuat oleh kepala sekolah yang mengungkapkan: "Kalau macam kami yang sudah lama, itu sudah macam pekerjaan rutin" (Wawancara Kepala Sekolah, 28 Agustus 2019).

Sedangkan Rusnia, menyatakan masih ditemukannya kendala dalam menyusun $\mathrm{RPPH}$ misalnya dalam hal pengkodean antara indikitor dalam kegiatan semester yang berbeda dengan indikator dalam kurikulum, sebagaimana dltuturkannya bahwa "ada kendala jadwal, kode di jadwal tidak sesuai dengan RPPH. Indicator tidak sesuai dengan yang ada di kurikulum. Kalau dulu sistem area pokoknya kita baku lihat contoh yang ada dalam buku, tanpa ada pelatihan" (Wawancara Guru R, 28 Agustu 2019).

Pada kelompok A, berdasarkan wawancara dengan Windasari, menurutnya RPPH disusun sendiri bukan hasil bersama para guru dan kepala sekolah tidak ada alasan yang dapat dijelaskan mengapa terjadi demikian Namun, menurutnya untuk pelajaran tahun 2019/2020 program belajar pada kelornpok A masih menggunakan panduan yang di keluarkan tahun 2014, sebagaimana wawancara guru W berikut: "Hanya rnasalah di kelompok saya itu RPPH itu sudah tiga tahun berjalan sudah mau masuk tahun keempat masih pakai yang dari tahun 2014. Jadi saya masih pakai yang lama sesuaikan dengan lndikator yang baru, saya ambil bahan buat kegiatan cocokan dengan indikator. Dari Kegiatan semester itu saya dituangkan ke $\mathrm{RPPH}^{\prime \prime}$ (Wawancara guru W 28 Agustus 2019).

Meskipun sebagian besar guru mengakui tidak ditemukan kendala dalam menyusun $\mathrm{RPPH}$, namun sepintas jika diamati RPPH juga dibuat seadanya menggunakan format yang sudah biasa dibuat sekolah ini. RPPH disusun/ditulis dalam buku besar bergaris ukuran folio. Pada bagian dalam buku, dibuat kolom-kolom yang terdiri atas nomor, indikator, kegiatan pembelajaran, alat/surnber belajar, kosakata, penilaian perkembangan anak, dan pengembangan karakter anak. Ada hal menarik terkait format RPPH ini, karena didapati pada kolom kosakata, ada guru yang menulisnya dengan alat dan tidak ada kolom pengembangan karakter anak. Ini berarti dalam membuat kolom untuk RPPH pada buku besar, antara guru yang satu dengan yang lain ada perbedaan. Beberapa bagian yang tidak sikron, justru, dapat menunjukkan bahwa guru sebenarnya memiliki kendala dalam membuatnya. Namun mengingat lidak adanya supervisi dari kepala sekolah, maka hal-hal yang demikian berlangsung terus menerus. Misalnya, pada bagian/kolom alat dan sumber belajar, masih ditemukan beberapa guru yang tidak dapat menguraikan dengan tepat. Selain itu pada bagian penilaian, dimana anak dinilai secara berkelompok dalam bentuk jumlah, seperti 12 anak mendapat angka dan seterusnya.

Saat studi ini dilakukan, ternyata sekolah ini baru tiga tahun menerapkan pembelajaran kurikulum 2013. Sebelumnya, sekolah menerapkan sistem KTSP, namun dari hasil wawancara dengan kepala sakolah diketahui bahwa sejak bagian dinas Pendidikan kabupaten wakatobi mengadakan pertemuan dengan guru-guru dan kepala sekolah di Wakatobi, maka keluarlah keputusan bahwa lembaga PAUD menerapkan kurikulum 2013, kurikulum 2013 cukup di lakukan pada satu kelas terlebih dahulu, namun atas inisiatif kepala sekolah, kurikulum 2013 di terapkan pada semua kelas.

Terkait dengan sistem kurikulum 2013, semua guru mengakui bahwasannya mereka mengalami kendala dengan system ini karena belum ada pelatihan berkaitan dengan keputusan tersebut. Hal lni dapat terbaca dan penuturan guru W, "Hanya kami belum dapat petunjuk yang jelas tentang bagaimana susunan sistem kurikulum 2013. Buka internet, PAUD beda-beda dalam membuat Kurikulum 2013" (Wawancara guru W, 28 Agustus 2019).

Senada dengan guru $\mathrm{W}$, bu guru $\mathrm{R}$ pun menambahkan bahwasannya guru membutuhkan waktu agar terbiasa dengan sistem kurikulum 2013, sebagaimana diungkapkannya bahwa"Kalau yang baru (kurikulum 2013) masih uji coba dengan kelas A. 
Dikasih buku dari dinas pendidikan, ibu kepala sekolah menyampaikan silahka di pelajari nanti dibuatkan kelas percontohan tentang proses pembelajaran kurikulum 2013" (Wawancara guru R, 28 Agustus 2019).

Evaluasi terhadap perencanaan pembelajaran umumnya menunjukkan kinerja perencanaan yang belum maksimal. Temuan evaluasi memperlihatkan perencanaan kegiatan semester tidak dilakukan oleh pihak sekolah. Perencanaan kegiatan semester disusun bersama melalui buku yang mereka pesan tanpa melakukan modifikasi tema sesuai dengan kebutuhan sekolah. Masih dari temuan evaluasi didapati program semester dan RPPH yang telah disusun, kemudian didistribusikan ke sekolah yang berada dalam satu gugus dan sekolah-sekolah tersebut membayar untuk membeli buku tersebut. Perencanaan kegiatan semester, dan penyusunan rencana kegiatan mingguan (RKM) tidak dilakukan oleh pihak sekolah.Perencanaan kegiatan semester dan rencana kegi- atan mingguan disusun bersama melalui wadah Ikatan Guru Taman Kanak-kanak Indonesia atau IGTKI dengan alasan solidaritas dan unity.Program semester dan rencana kegiatan mingguan (RKM) yang telah disusun, kemudian didistri- busikan ke sekolah yang berada dalam satu gugus dan sekolah-sekolah tersebut membayar ke IGTKI (V \& Anamara, 2014).

Gambaran di atas sebenarnya hendak menggambarkan kondisi di lapangan bahwa sebetulnya para guru kelompok bermain Nur'ain masih belum paham bagaimana menyusun kurikulum, program semester, maupun RPPH. Sehingga salah satu upaya untuk mengatasinya, dibuatlah kesepakatan diantara para guru untuk menyusun kegiatan pembelajaran kelompok bermain Nur'ain dengan cara membeli buku. Di pihak lain, kondisi ini menunjukkan ketidakmampuan Dinas Pendidikan Kabupaten untuk menghadirkan pembelajaran yang bermutu di Kelompok Bermain Nur'ain. Pembinaan berlangsung tidak serius, menyerahkan kepada masing-masing sekolah, dan minim pelatihan karena dinas sendiri tidak memiliki tenaga kompeten yang membidangi PAUD serta biaya. Padahal jika diperhatikan secara seksama kualifikasi yang diminta dari guru PAUD adalah kemampuannya untuk menyusun kurikulum dan lain-lain terkait pembelajaran di kelas. Jika kondisi ini terus berlangsung dapat dipastikan kompetensi seperti ini tidak dapat dikuasai oleh guru yang ada di sekolah ini padahal guru anak usia dini khususnya anak usia PAUD, membutuhkan kemampuan berupa keterampilan mengatur berbagai variasi perubahan dan sinergi di dalam kelas, sebab anak PAUD berkembang dan berubah secara terusmenerus dalam proses pembelajaran.

Jika diamati kegiatan semester sekolah ini, maka akan terlihat adanya pengulangan pembahasan/copy paste pada tiap lingkup pengembangan anak yang diuraikan, hanya temanya saja yang berubah. Ini mengindikasikan guru-guru yang terlibat dalam penyusunan kurikulum tidak mampu untuk membuat program kegiatan semester. Pada rencana kegiatan semester yang dibentuk menyerupai jarring laba-laba, didapati adanya kalimat perintah, maksudnya konsep kegiatan pada tiap area dirumuskan dengan kalimat bernada suruhan Artinya kegiatan belajar di Kelompok Bermain Nur'ain ini, memang di setting teacher oriented.

Dalam penyusunan rencana pelaksanaan pembelajaran harian (RPPH), temuan evaluasi menunjukkan pembuatan RPPH dilakukan oleh para guru dan kepala sekolah di sekolah. Tanpa ada scedule yang dibuat kepala sekolah, guru-guru bebas menyusun RPPH bias untuk seminggu atau penyusunan bisa dilakukan sehari sebelum kegiatan pembelajaran berlangsung. Rata-rata guru mengatakan hampir tidak ada kendala yang berarti dalam membuat RPPH karena pengalaman mengajar yang tinggi, namun masih ditemukan adanya perbedaan format antara guru yang satu dengan yang lain.

\section{Pelaksanaan Pembelajaran.}

Pembelajaran yang telah di susun dalam bentuk program semester dan rencana pelaksanaan pembelajaran harian/RPPH seyogyanya diimplementasikan dalam kegiatan pembelajaran di kelas. Bagaimana Kelompok Bermain Nur'ain melaksanakan kegiatan 
pembelajaran?. Dari data yang dihimpun, diketahui bahwa kegiatan belajar mengajar di lembaga ini dlrnulai pada pukul 7.30 pagi hingga pukul 10.00. Kegiatan pembelajaran telah sesuai dengan tuntutan standar PAUD yang rnengharuskan kegiatan belajar mengajar di PAUD terdiri atas tiga rangkaian, yakni pembukaan, inti, dan penutup.

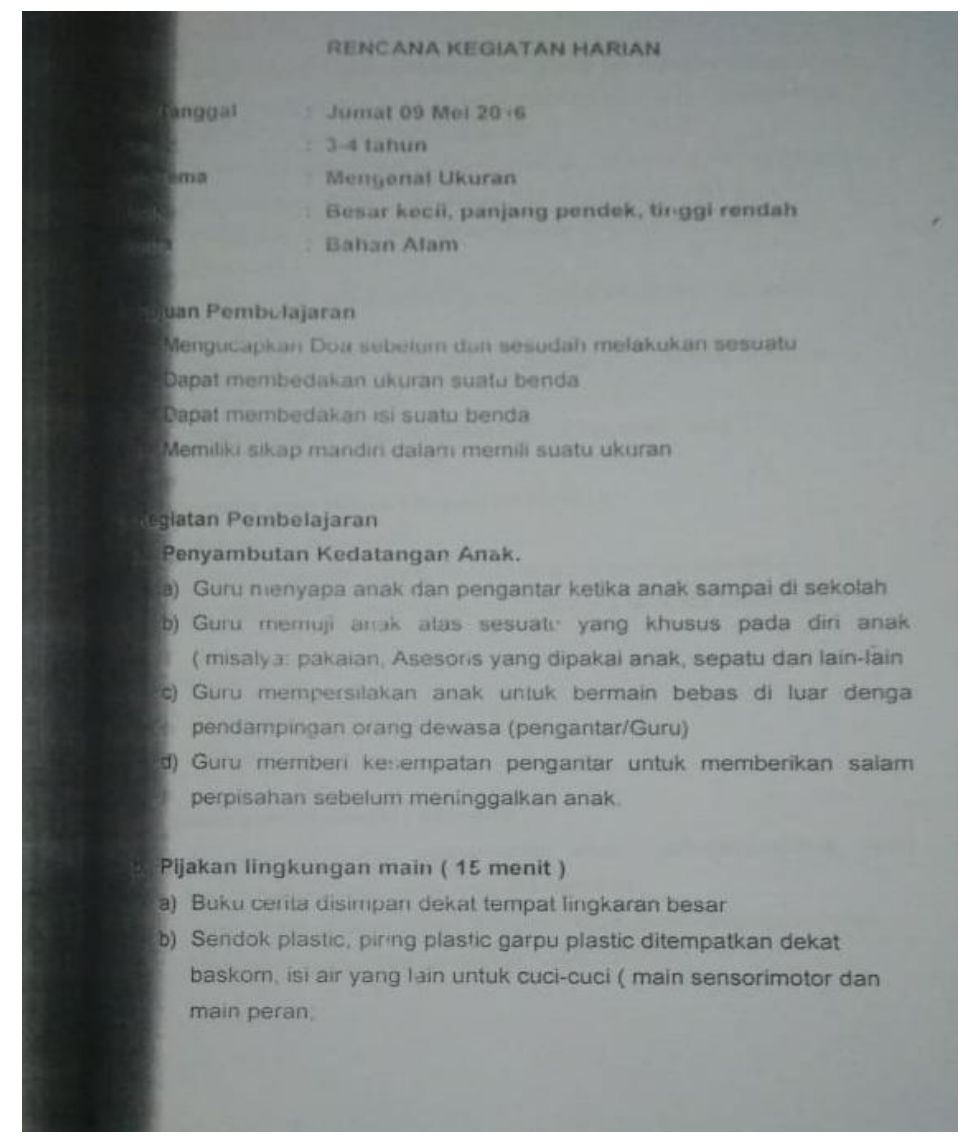

\section{Gambar RPPH KB Nur'ain}

Nampak pada gambar di atas pelaksanaan kegiatan mengajar yang disusun oleh para guru dan kepala sekolah, namun dalam observasi kami tidak dapat menemukan dengan pasti apa sebenarnya yang sudah dibuat mereka jalan sesuai yang telah mereka rencanakan atau tidak. Saa wawancara dengan kepala sekolah dan para guru tidak terungkap kegiatan pembelajarannya yang dimaksud dalam kegiatan yang mereka sudah susun dalam RPPH.

Berdasarkan wawancara dengan guru, diketahul bahwa ada kegiatan bersama yang biasanya dilakukan oleh dua rombongan belajar sebelum mengikuti kegiatan pembukaan, inti, dan penutup di kelasnya, masing-masing kegiatan bersama yang dimaksud adalah temu pagi, berbaris di depan ruangan, dan breafing singkat dari guru yang bertugas sebagai piket pada hari tersebut, hal ini sebagaimana dituturkan oleh guru R: "Anak datang pagi tidak bermain di luar, langsung temu pagi dulu. setelah itu baris di depan kelas, anak-anak aktif bertanya (Wawancara Guru R, 29 Agustus 2019).

Dari wawancara guru, umumnya informasi yang diperoleh menyatakan bahwa kegiatan dimulai dengan temu pagi kemudian dilanjutkan dengan berbaris di depan ruangan, tanya jawab seputar kegiatan anak-anak pada hari kemarin, bernyanyi, berdoa dan kemudian menuju kelas masing-masing, seperti yang diungkapkan bu guru W: dari awal itu, bel masuk semua anak dikumpulkan di depan kelas, awalnya nyanyi Bersama dengan gerakannya. Selesai, guru piket yang memimpin, ada tanya jawab dari guru piket tentang tema hari ini, setelah itu anak kembali masuk kelas (Wawancara Guru W, 29 Agustus 2019). 
Kegiatan pembuka atau yang biasa disebut kegiatan awal di Kelompok Bermain ini biasanya klasikal, dimana anak beridiri di depan kelas untuk berbaris, story telling atau bercerita mengenai pengalaman yang dialami anak pada hari kemarin. Kegiatan ini tidak bertalu untuk setiap anak, hanya beberapa anak saja yang bercerita sebagai perwakilan. Dengan berlalunya kegiatan awal, maka kegiatan berikutnya adalah kegiatan inti, biasanya guru akan menjelaskan kepada anak tema apa yang akan dipelajari pada hari itu dan membuka tiga kelas untuk belajar anak. Setelah menyelesaikan penjelasannya, guru mempersilahkan anak untuk menuju kelasnya masing-masing, dan biasanya anak akan memilih kelas berdasarkan kelompoknya. Kegiatan anak di kelas akan berakhir ketika bel tanda istirahat dibunyikan pada pukul 9.00. Dengan demikian berakhirlah kegiatan inti, hal ini sebagaimana diungkapkan bu guru $R$ setelah itu mulai dengan perjelasan 3 kegiatan yang diajarkan, terus anaknya menuju kegiatannya masing-masing di dalam kelas yang di pimpin oleh masing-masing guru kelas sampai dengan jam 9 tepat bunyi bel istrahat, 30 menit istirahat kemudian cuci tangan dan makan setelah itu kembali lagi ke kelas masingmasing (Wawancara guru R, 29 Agustus 2019).

Pada kegiatan inti, anak belajar sesuai dengan tema dan sub tema yang diberikan pada hari itu, namun untuk kelas kelompok B kegiatan belajar lebih banyak diarahkan pada membaca, menulis dan berhitung (calistung) dengan suasana belajar layaknya di sekolah dasar. Namun itulah fakta yang dihadapi anak usia dini umumnya di Lembaga PAUD. Rangkaian terakhir pembelajaran adalah kegiatan penutup, yang biasanya dilaksanakan setelah anak istirahat. Pada kegiatan penutup, guru melakukan recalling kepada peserta didik terkait pembelajaran yang sudah dilakukan pada hari itu, beryanyi, doa penutup dan pulang ke rumah, seperti yang dituturkan bu guru W bahwa "30 menit penutup doa, segala macam, tanya jawab bahan yang diajarkan lbu guru, tanya ulang lagi nama hari, nama bulan pokoknya sesuai dengan kreatif guru masing-masing terus pamit ke guru, kepala sekolah dan menuju ke halaman kelas dan ke orang tua masingmasing (Wawancara guru W, 29 Agustus 2019).

Akan tetapi, dengan adanya perubahan sistem kurikulum 2013 yang sudah berlangsung tiga tahun, guru-guru harus belajar bagaimana cara mengelola pembelajaran dengan kurikulum 2013. Evaluasi pada bagian pelaksanaan umumnya menunjukan hasil yang kurang maksimal dibanding dengan aturan standar PAUD. Memang sudah ada penataan lingkungan ruang kelas dan pengorganisasian kegiatan, namum terkesan menyerupai keadaan pada SD awal. Semua ruang kelas di Kelompok Bermain Nur'ain telah di setting secara permanen, maksudnya area dan peralatan telah ditetapkan pada lokasi masing-masing dengan maksud tidak akan berubah lagi pada kegiatan belajar seterusnya sampai anak meninggalkan kelompok bermain Nur'ain. Kondisi seperti ini memperlihatkan bahwa guru tidak melakukan penataan ulang untuk kegiatan belajar hari-hari selanjutnya, meski sebenarnya guru memiliki otoritas untuk mengubah lingkungan kelas anak guna mendukung proses kegiatan belajar yang menarik dan tidak membosankan.

Selain itu, temuan penelitian menunjukkan bahwa penggunaan alat permain edukatif (APE) pada saat kegiatan selalu sama, meskipun dari sisi keamanan sesuai bagi anak karena umumnya material berbahan plastik dan kayu. Namun dari sisi kesehatan sangat relatif karena ada material yang terawatt dan sebagiannya tidak, dengan kondisi usang dan berdebu. Alat-alat ini juga tidak sepenuhnya sesuai dengan fungsi, stimulasi yang telah direncanakan karena terkesan hanya untuk memenuhi syarat yakni setiap area ada materialnya tanpa mempertimbangkan sebetulnya material apa yang sesuai dengan area serta bidang pengembangan anak. Jika dilihat kembali pada rumusan visi Kelopok bermain Nur'ain ini bahwa menjadikan anak memeliki karakter sejak usia dini, keadaan ini hampir tidak relevan dengan pelaksanaan pembelajaran yang jauh dari kesan menciptakan karakter-karakter anak sejak usia dini. Konsep yang dipahami guru tentang karakter sangat sederhana seperti memberikan keteladanan yang baik kepada anak-anak dalam hal bersikap,berbicara dan menghargai teman dan guru. Temuan penelitian pembukaan yang 
dilakukan hanya kegiatan apersepsi yaitu absen pagi yang dilakukan oleh guru. Namun, tidak ada pengulangan atau penguatan mengenai materi yang sudah diajarkan. Kegiatan inti pembelajaran masih berfokus pada pendidik. Anak tidak secara aktif melakukan eksplorasi pada kegiatan yang diberikan. Kegiatan inti pada anak usia dini seharusnya dilakukan sesuai dengan tema yang telah ditetapkan dan disusun di dalam rencana kegiatan. Guru masih terfokus terhadap kemampuan anak terhadap calistung sehingga materi pembelajaran yang diberikan tidak sesuai dengan materi pembelajaran yang sesuai dengan tahapan perkembangan anak. Kegiatan penutup yang dilakukan adalah dengan pemberian tugas dan berdoa bersama. Tidak ada penguatan kegiatan yang telah dilakukan pada hari tersebut (Hartati, 2017).

Temuan lain terkait pengorganisasian kegiatan menunjukkan kegiatan pembelajaran lebih dominan di lakukan dalam ruang kelas, kegiatan outdoor sebatas bermain saat jam istirahat, olahraga dan apel pada saat masuk kelas. Meski pengelolaan kegiatan sudah terdiri atas kegiatan pembuka, kegiatan inti dan penutup, namum ditemukan tidak ada perbedaan antara pengelolaan kegiatan kelompok besar dan kelompok kecil karena semua kegiatan berpusat kepada guru. Hal lainnya, Kelompok Bermain Nur'ain ini menekankan kegiatan yang syarat kognisi yakni membaca, menulis dan berhitung sehingga semua kegiatan belajar diarahkan agar anak dapat menguasai ketiga hal itu, ini dapat di lihat pada program kegiatan semester dan RPPH yang mengarah pada calistung. Masih ada anggapan bahwa anak yang akan masuk ke SD awal harus dapat menguasai calistung, apalagi jika anak pernah belajar di PAUD. Anggapan ini bukan saja ada dalam benak kepala sekolah dan guru, namun orang tua anak juga memiliki cara pandang yang sama sehingga tidak ada keberatan dengan proses pembelajaran yang semi sekolah dasar bisa diterapkan di lingkungan Kelompok Bermain Nur'ain.

\section{Penilaian Pembelajaran.}

Meskipun dalam wawancara yang dilakukan dengan kepala sekolah diperoleh informasi bahwa penilaian terhadap perkembangan peserta didik dilakukan bervariasi, seperti melalui pengamatan, penugasa, unjuk kerja, pencatatan anekdot, percakapan/dialog, laporan orang tua dan dokumentesi hasil karya anak (portotolio), serta deskripsi profil anak, namun dari wawancara dengan guru diperoleh informasi bahwa penilaian kepada peserta didik cenderung dilakukan melalui pengamatan dan unjuk kerja.

Biasanya guru menilai peserta didik dengan cara mengamati peserta didik saat kegiatan belajar atau pada saat anak unjuk kerja, seperti yang diungkapkan kepala sekolah: "Waktu anak-anak kerja, bu guru langsung lihat anak yang sudah bisa, ini belum bisa (Wawancara Kepala Sekolah, 29 Agustus 2019). Selanjutnya guru akan memberi symbol angka untuk menilai kemampuan anak. Jumlah angka yang diberikan menunjukkan kemampuan yang dimiliki anak, yakni angka satu artinya belum berkernbang, angka dua mulai berkembang, angka tiga berkembang sesuai harapan, dan angka empat berkembang sangat baik, seperti yang dituturkan kepala sekolah angka satu belum berkembang, angka dua mulai berkembang, angka tiga berkembang sesuai harapan, dan angka empat berkembang sangat baik. Anak yang angka empat bu guru hanya menyampaikan dia sendiri buat bagus sekali, angka tiga dia dibantu sedikit, angka dua ibu guru bantu, bintang satu dia belum tau apa-apa. Penilaian ini kami dapat waktu pelatihan tahun 2013, berdasarkan Permen No 58 Tahun 2009 dan Permendikbud No. 137 tahun 2014 (Wawancara Kepala Sekolah, 29 Agustus 2019).

Para guru melakukan penilaian terhadap peserta didik menggunakan buku besar yang sudah dipersiapkan sebelumnya, guna mencatat kemajuan atau progress anak didiknya. Dalam wawancara dengan bu guru $\mathrm{W}$, diketahui bahwa format penilaian perkembangan anak terintagrasi dalam rencana pelaksanaan pembelajaran harian/RPPH, seperti yang diungkapkannya bahwa "penilaian itu ada format penilaian dibuat sekaliaan dengan RPPH. Buku RPPH satu buku penilaian satu. Nanti kita lihat anak ini bisa kasih 
angka berapa. Aspek yang dinilai dilihat dengan kegiatan belajar mengajar, misalnya di area matematika dia punya kegiatan membilang 1-20 kemampuannya, ucapan, urutannya itu yang dinilai (Wawancara Guru W, 29 Agustus 2019).

Perkembangan anak di Kelompok Bermain Nur'ain tidak dicatat secara individu, namun perkembangan antara anak yang satu dengan yang lainnya digabung bersama. Penilaian yang terlihat hanyalah dalam bentuk jumlah angka tanpa narasi atau keterangan yang menjelaskan capaian anak. Meskipun demikian, sisi positifnya adalah aspek perkembangan yang dinilai masih sesuai, dengan ketentuan yang ada yakni agama dan moral, fisik, kognitif, bahasa, social emosional dan seni. Penelitian di RA Darur Rohmat menemukan bahwa Kepala PAUD dan bukti pendukung yang ada bahwa penilaian perkembangan anak dilakukan setiap hari, tetapi tidak didokumentasikan dengan tertib. Penilaian perkembangan anak dilakukan melalui teknik observasi, hasil karya dan catatan anekdot. Penilaian perkembangan observasi di TKS Al-Hidayah menggunakan simbol bintang dan di RA Darur Rohmat menggunakan ceklis (Utami et al., 2019).

Temuan evaluasi memperlihatkan bahwa teknik penilaian pada peserta didik di Kelompok Bermain Nur'ain relatif belum sesuai dengan aturan dalam standar PAUD meski tidak semua teknik ini dipakai karena yang dominan digunakan hanya melalui pengamatan dan unjuk kerja. Hal lain yang ditemukan, penilaian anak tidak dilakukan secara kualitatif atau melalui narasi/deskripsi yang menjelaskan capaian anak didik, sebaliknya penilaian dilakukan dengan cara memberi tanda angka. Tiap jumlah angka mewakili kemampuan anak didik. Namun cara ini tidak fair, karena penilaian seperti ini tidak dilakukan per individu melainkan kemampuan beberapa anak digabung menjadi satu dengan tanda angka. Meski demikian, penilaian yang dilakukan sudah memperhatikan tingkat capaian perkembangan peserta didik, namun dalam hal status kesehatan masih belum ditemukan.

\section{SIMPULAN}

Perencanaan dan penyusunan program semester dan kegiatan harian masih dilakukan oleh para guru dengan menyontek buku yang dibeli. Kelompok Bermain Nur'ain baru sebatas membuat rencana kegiatan harian sesuai dengan buku tanpa melakukan modifikasi. Hal ini tentu saja menimbulkan pertanyaan mengapa kebiasaan ini terus dipertahankan padahal sekolah-sekolah seharusnya mampu membuat perencanaan pembelajarannya sendiri. Dengan demikian, pada aspek proses sekolah ini belum sesuai dengan standar PAUD. Kegiatan pelaksanaan pembelajaran meliputi pembukaan, inti dan penutup sebagaimana tertuang dalam standar PAUD. Namum kegiatan masih dominan terjadi di dalam kelas dengan suasana teacher center yang menekankan pembelajaran pada kognisi anak. Dari sisi metode pembelajaran, maka belum sesuai dengan standar PAUD. Yang dapat dikatakan menyangkut penilaian adalah pertama Kelompok Bermain Nur'ain ini melakukan penilaian melalui pengamatan dan unjuk kerja. Namun, penilaian tersebut tidak dicatat secara individu melalui narasi melainkan berkelompok dengan memakai simbol angka.

\section{DAFTAR PUSTAKA}

Anhusadar, L. O. (2016). Kreativitas Pendidikan Di Lembaga PAUD. Al-Ta'dib, 9(1), 76-93.

Anhusadar, L. O. (2018). Perkembangan Otak Anak Usia Dini. Jurnal Shautut Tarbiyah, (May), 98-113.

Anhusadar, L. O., \& Islamiyah, I. (2019). Taman Layak Anak Usia Dini di Kota Kendari. Jurnal Obsesi : Jurnal Pendidikan Anak Usia Dini, 3(1), 117. https:// doi.org/10.31004/obsesi.v3i1.143

Gunartha, I. W., Kartowagiran, B., \& Suardiman, S. P. (2014). Pengembangan Model Evaluasi Program Layanan Pendidikan Anak Usia Dini (PAUD). Jurnal Penelitian Dan Evaluasi Pendidikan, 18(1), 30-43. https:// doi.org/10.21831/pep.v18i1.2122 
DOI: $10.31004 /$ obsesi.v4i2.485

Hartati, S. (2017). Penyelenggaraan Program PAUD (Studi Evaluatif di Pos PAUD Kota Jakarta Timur, Provinsi Dki Jakarta). JIV-Jurnal Ilmiah Visi, 12(2), 155-162. https://doi.org/10.21009/jiv.1202.8

Kasrani. (2016). Evaluasi Program Pendidikan Anak Usia Dini (PAUD). Manajemen Pendidikan, 25 (2)(1998), 233-243.

Kurniawan, D., Dwikurnaningsih, Y., \& Sulasmono, B. S. (2018). Evaluasi Program Supervisi Akademik di PAUD Swasta. Kelola: Jurnal Manajemen Pendidikan, 5(2), 107-123. https://doi.org/10.24246/j.jk.2018.v5.i2.p107-123

Marwah. (2017). Evaluasi Penyelenggaraan Program Pendidikan Anak Usia Dini Pada Taman Penitipan Anak Di Kota Makassar.

Munawar, M., Prasetyo, A., \& Pusari, R. W. (2013). Pengembangan model pembelajaran inovatif melalui pendekatan in house training berbasis kearifan budaya lokal. PAUDIA, 2(1), 1-13.

Musfiroh, T. (2008). Bermain Sambil belajar dan Mengasah Kecerdasan. Jakarta: Depdiknas.

Oktaria, R. (2014). Evaluasi Program Implementasi Pendekatan Beyond Centers And Circle Time ( BCCT ) PAUD PPS Universitas Negeri Jakarta. Jurnal Pendidikan Usia Dini, 8(2), 337-352.

Renti Oktaria. (2019). Evaluasi Program Penataan Lingkungan Bermain Berbasis Hubungan Sosial Anak Di RA Istiqlal Jakarta Pusat. Journal of Chemical Information and Modeling, 53(9), 1689-1699. https:// doi.org/10.1017/CBO9781107415324.004

Sumantri. (2005). Model Pengembangan Keterampilan Motorik Anak Usia Dini. Jakarta: Departemen Pendidikan Nasional.

Suyadi. (2010). Psikologi Belajar PAUD. Yogyakarta: Pustaka Insan Madani.

Utami, W. Y. D., Jamaris, M., \& Meilanie, S. M. (2019). Evaluasi Program Pengelolaan Lembaga PAUD di Kabupaten Serang. Jurnal Obsesi : Jurnal Pendidikan Anak Usia Dini, 4(1), 67. https://doi.org/10.31004/obsesi.v4i1.259

V, M. G., \& Anamara. (2014). Evaluasi Program Implementasi standar PAUD. Jurnal Pendidikan Anak Usia Dini, 8(2).

Widiastuti, A. A. (2018). Implementasi Standar Sarana Dan Prasarana Paud Di Lembaga Taman Penitipan Anak (Tpa). PAUDIA : Jurnal Penelitian Dalam Bidang Pendidikan Anak Usia Dini, 7(1).

Yati, F., \& Yaswinda, Y. (2019). Penerapan Model Evaluasi CIPPO dalam Mengevaluasi Penyelenggaraan Lembaga PAUD. Jurnal Obsesi : Jurnal Pendidikan Anak Usia Dini, 4(1), 30. https://doi.org/10.31004/obsesi.v4i1.238 